\title{
Insights into Structural Transformations in the Local Structure of Li2VO2F Using Operando X-ray Diffraction and Total Scattering: Amorphization and Recrystallization
}

Baur, Christian; Lacatusu, Monica-Elisabeta; Fichtner, Maximilian; Johnsen, Rune E.

Published in:

ACS Applied Materials and Interfaces

Link to article, DOI:

10.1021/acsami.0c02391

Publication date:

2020

Document Version

Version created as part of publication process; publisher's layout; not normally made publicly available

Link back to DTU Orbit

Citation (APA):

Baur, C., Lacatusu, M-E., Fichtner, M., \& Johnsen, R. E. (2020). Insights into Structural Transformations in the Local Structure of Li2VO2F Using Operando X-ray Diffraction and Total Scattering: Amorphization and Recrystallization. ACS Applied Materials and Interfaces, 12(24), 27010-27016.

https://doi.org/10.1021/acsami.0c02391

\section{General rights}

Copyright and moral rights for the publications made accessible in the public portal are retained by the authors and/or other copyright owners and it is a condition of accessing publications that users recognise and abide by the legal requirements associated with these rights.

- Users may download and print one copy of any publication from the public portal for the purpose of private study or research.

- You may not further distribute the material or use it for any profit-making activity or commercial gain

- You may freely distribute the URL identifying the publication in the public portal 


\title{
Insights into Structural Transformations in the Local Structure of $\mathrm{Li}_{2} \mathrm{VO}_{2} \mathrm{~F}$ Using Operando X-ray Diffraction and Total Scattering: Amorphization and Recrystallization
}

\author{
Christian Baur,* Monica-Elisabeta Lǎcătuşu, Maximilian Fichtner, and Rune E. Johnsen
}

Cite This: https://dx.doi.org/10.1021/acsami.0c02391

Read Online

ACCESS | Lلll Metrics \& More | 国 Article Recommendations ｜ sl Supporting Information

ABSTRACT: Disordered rock salt $\mathrm{Li}_{2} \mathrm{VO}_{2} \mathrm{~F}$ cathode material for lithium-ion batteries was investigated using operando X-ray diffraction and total scattering to gain insight into the structural changes of the short-range and long-range orders during electrochemical cycling. The $\mathrm{X}$-ray powder diffraction data show the well-known pattern of the disordered rock salt cubic structure, whereas the pair distribution function (PDF) analysis reveals significant deviations from the ideal cubic structure. During battery operation, a reversible rock salt-toamorphous phase transformation is observed, upon $\mathrm{Li}$ extraction and reinsertion. The X-ray total scattering data show strong indications of the formation of tetrahedrally coordinated $\mathrm{V}$ in a nondisordered rock salt phase of the charged electrode material. The results show that the

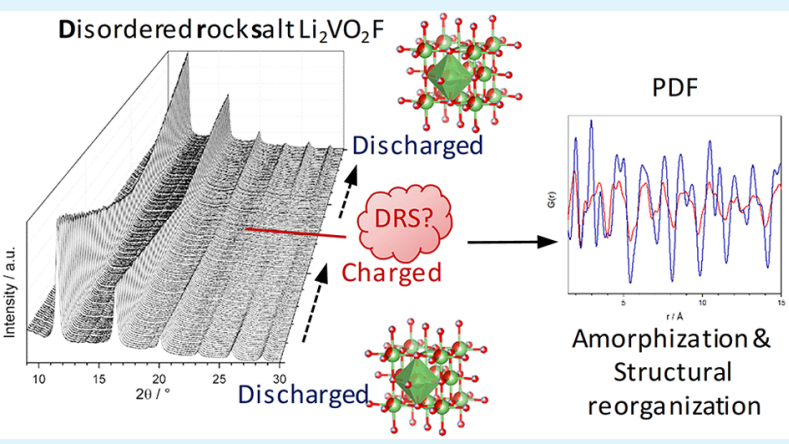
disordered rock salt $\mathrm{Li}_{2} \mathrm{VO}_{2} \mathrm{~F}$ material undergoes a hidden structural rearrangement during battery operation.

KEYWORDS: X-ray powder diffraction, pair distribution function analysis, Li-ion batteries, disordered rock salt, Li-rich FCC

\section{INTRODUCTION}

Lithium-rich disordered rock salt (DRS)-type materials like $\mathrm{Li}_{2} \mathrm{VO}_{2} \mathrm{~F}$ have become widely studied in the past years. ${ }^{1-3}$ Their high reversible discharge capacity $\left(>300 \mathrm{~mA} \mathrm{~h} \mathrm{~g}^{-1}\right)$ in lithium-ion batteries (LIB) makes them a promising candidate as a future generation of cathode materials. In Li-rich DRS materials, $\mathrm{Li}$ and one or more electrochemical active transition metals (TM) are randomly distributed at the same lattice positions (Wyckoff $4 a$ ) in a cubic rock salt lattice $(F m \overline{3} m$ ). Oxygen (and fluorine) ions are randomly distributed at the Wyckoff $4 b$ position and octahedrally coordinated to the cations. According to the percolation theory of Urban et al., the $\mathrm{Li}$ excess in the structure ( $\mathrm{Li}: \mathrm{TM} \geq 1.1$ ) enables macroscopic Li diffusion paths via certain tetrahedral interstices. ${ }^{4}$ Disordered rock salt transition-metal oxides are currently mostly synthesized by mechanochemical ball milling. This simple but flexible approach has led to a vast variety different compounds (e.g., $\mathrm{Li}_{2} \mathrm{MoO}_{2} \mathrm{~F}, \mathrm{Li}_{2.1} \mathrm{Mo}_{0.7} \mathrm{Ti}_{0.2} \mathrm{O}_{2} \mathrm{~F}$, $\mathrm{Li}_{2} \mathrm{~V}_{x} \mathrm{Cr}_{1-x} \mathrm{O}_{2} \mathrm{~F}, \quad \mathrm{Li}_{2} \mathrm{MnO}_{2} \mathrm{~F}, \quad \mathrm{Li}_{1.25} \mathrm{Nb}_{0.25} \mathrm{~V}_{0.5} \mathrm{O}_{2}$, $\mathrm{Li}_{1.2} \mathrm{Ni}_{0.33} \mathrm{Ti}_{0.33} \mathrm{Mo}_{0.13} \mathrm{O}_{2}, \quad \mathrm{Li}_{2} \mathrm{~V}_{0.5} \mathrm{Ti}_{0.5} \mathrm{O}_{2} \mathrm{~F}$ or $\mathrm{Li}_{2} \mathrm{~V}_{0.5} \mathrm{Fe}_{0.5} \mathrm{O}_{2} \mathrm{~F}$, $\mathrm{Li}_{x} \mathrm{VO}_{2} \mathrm{~F}$, and $\mathrm{Li}_{1.25} \mathrm{Ni}_{0.45} \mathrm{Ti}_{0.3} \mathrm{Mo}_{0.1} \mathrm{O}_{1.85} \mathrm{~F}_{0.15}$ ) in the past years. $^{5-13}$ However, due to the nature of the synthesis conditions, the resulting materials are nanocrystalline. In combination with the disorder nature of the structure itself, detailed X-ray diffraction analysis and a precise description of the structure are challenging, even with synchrotron X-ray radiation. Only a few studies have investigated Li-rich DRS structures using synchrotron X-ray powder diffraction (XRPD) or X-ray total scattering in greater detail. Especially, the pair distribution function (PDF) analysis of total scattering data is a powerful method to investigate the local atomic structure of amorphous and disordered nanocrystalline materials. ${ }^{14,15}$ The PDF analysis provides a histogram of atomic distances within the material, where the peak positions in the PDF correspond to specific atom-atom distances and the peak intensities correspond to their abundance in the material. Even without an exact structural model, e.g., derived from a Rietveld refinement of XRPD data, information about the local structure can be extracted. Furthermore, fitting the PDF data to a crystallographic model can help to identify different phases, which are hard to detect by the classical XRPD, even if they are nanocrystalline or amorphous. ${ }^{14}$ Only a few studies have investigated Li-rich DRS structures by synchrotron XRPD or total scattering in greater detail, e.g., $\mathrm{Li}_{1.2} \mathrm{Ti}_{0.35} \mathrm{Ni}_{0.35} \mathrm{Nb}_{0.1} \mathrm{O}_{1.8} \mathrm{~F}_{0.2}$ by Zhao et al. ${ }^{16}$ The first PDF analysis of $\mathrm{Li}_{2} \mathrm{VO}_{2} \mathrm{~F}$ was conducted by Chen et al. in $2015 .{ }^{17} \mathrm{It}$ indicated deviations from the ideal cubic structure in the local

Received: February 7, 2020

Accepted: May 26, 2020

Published: May 26, 2020 

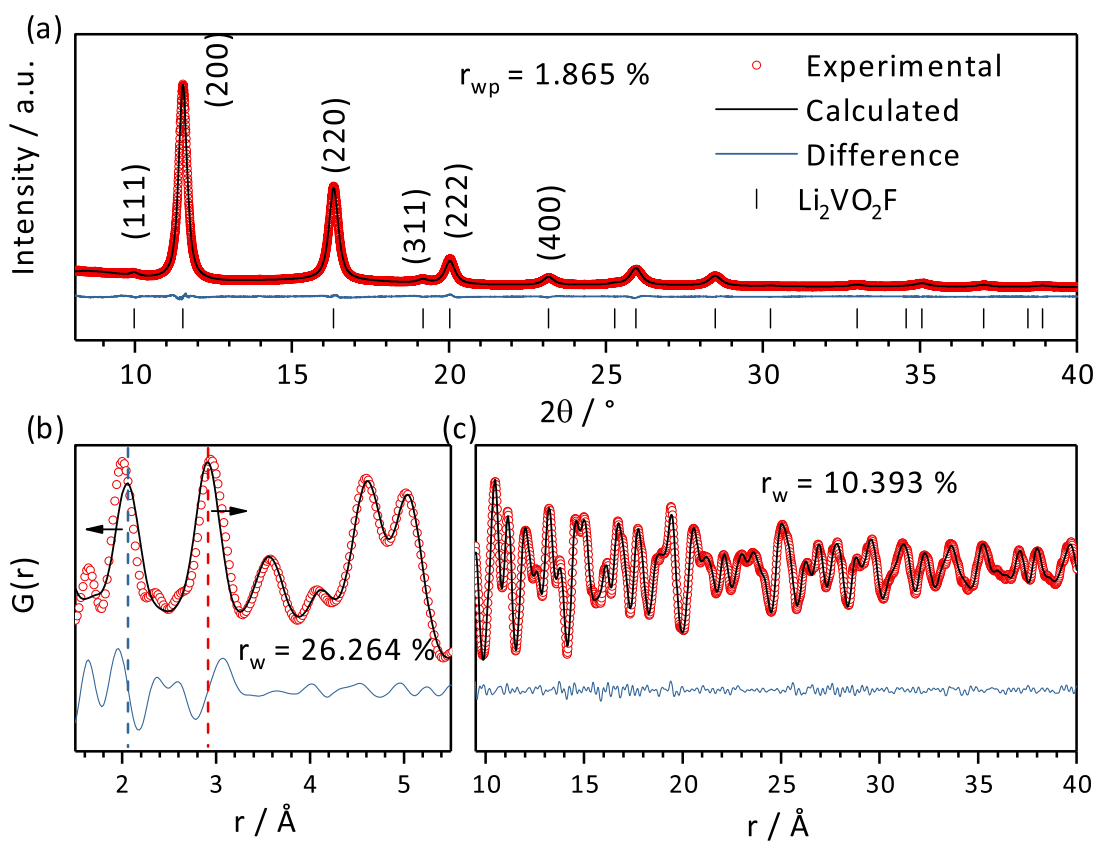

Figure 1. (a) XRPD pattern and Rietveld refinement plot of pristine $\mathrm{Li}_{2} \mathrm{VO}_{2} \mathrm{~F}, \lambda=0.41324 \AA$. (b) Refinement of the corresponding PDF pattern in the $r$ range of 1.5-5.5 A. Deviations of the local structure are indicated with dashed lines. (c) Refinement of the corresponding PDF pattern in the $r$ range of $9.5-40.0 \AA$.

structure. However, both studies only focused on the pristine materials.

Herein, we report the first study of $\mathrm{Li}_{2} \mathrm{VO}_{2} \mathrm{~F}$ investigating the structural evolution during delithiation and lithiation by operando synchrotron XRPD and total diffraction with pair distribution function analysis during battery operation. Significant deviation from the ideal cubic structure has been observed in the local scale in the pristine material. Amorphization and the loss of the DRS structure accompanied with the formation of tetrahedrally coordinated $\mathrm{V}$ during $\mathrm{Li}$ extraction, along with recrystallization upon $\mathrm{Li}$ reinsertion, were observed. Our findings suggest that the charged state of $\mathrm{Li}_{2} \mathrm{VO}_{2} \mathrm{~F}$ is a combination of at least two phases: amorphous and DRS-like. This study reveals the importance of gaining insight into the changes of the local structure in Li-rich DRS materials to understand the electrochemical processes during battery operation.

\section{RESULTS AND DISCUSSION}

2.1. Characterization of $\mathrm{Li}_{2} \mathrm{VO}_{2} \mathrm{~F}$ by X-Ray Diffraction and Total Scattering. $\mathrm{Li}_{2} \mathrm{VO}_{2} \mathrm{~F}$ has been synthesized following a high-energy ball milling approach, ${ }^{1,11}$ yielding a nanocrystalline material. Figure 1a shows a Rietveld refinement plot of the pristine $\mathrm{Li}_{2} \mathrm{VO}_{2} \mathrm{~F}$-based DRS structure with the space group $F m \overline{3} m$. Broad peaks indicate the nanocrystalline nature of the material. The lattice parameter $a=4.115(2) \AA$ is comparable to previous reports found in the literature. ${ }^{1,11}$ The crystallite size was determined using a volume-weighted mean column length, $L_{\mathrm{vol}}$, of $11.5(2) \mathrm{nm}$, which yields a crystallite size of $8.9(2) \mathrm{nm}$ assuming a typical log-normal size distribution. ${ }^{18}$ No crystalline impurity phases were observed in the diffraction pattern. Further structural parameters can be found in the Supporting Information (Table S1).

In the analysis of the X-ray powder diffraction pattern using the Rietveld method, we assume a translation symmetry. Thus, the analysis of an XRPD pattern yields the average information of the crystalline bulk material. The short-range disorder in the structure is not described by XRPD but can be better analyzed using total scattering and PDF analysis. Figure $1 \mathrm{~b}, \mathrm{c}$ shows the PDF fit of $\mathrm{Li}_{2} \mathrm{VO}_{2} \mathrm{~F}$. For the PDF fit, we used a structural model derived by the Rietveld refinement. The PDF pattern can be divided into two parts: the short-range local structure up to $6 \AA$ and the longer-range local structure above $10 \AA$. The fit with the DRS structure does not describe the local scale particularly good $\left(r_{\mathrm{w}}=26.264 \%\right)$. The peaks at around $2.00 \AA$ (blue line) and $2.95 \AA$ (red line) (Figure $1 \mathrm{~b}$ ) correspond to the $\mathrm{V} / \mathrm{Li}-\mathrm{O} / \mathrm{F}$ and $\mathrm{V} / \mathrm{Li}-\mathrm{V} / \mathrm{Li}($ or $\mathrm{O} / \mathrm{F} /-\mathrm{O} / \mathrm{F}$ ) distances in the ideal cubic structure. The first $\mathrm{V} / \mathrm{Li}-\mathrm{O} / \mathrm{F}$ distance in the PDF is shorter than that in the model, whereas the second distance of $\mathrm{V} / \mathrm{Li}-\mathrm{V} / \mathrm{Li}$ ( or $\mathrm{O} / \mathrm{F} /-\mathrm{O} / \mathrm{F}$ ) is larger compared to that of the structural model derived by the Rietveld refinement. Similar observations have been also reported by Chen et al. ${ }^{17}$ The third distance at $3.57 \AA$, corresponding to the next nearest $\mathrm{V} / \mathrm{Li}-\mathrm{O} / \mathrm{F}$ distance, matches relatively well with the model, whereas the next $\mathrm{V} / \mathrm{Li}-\mathrm{V} / \mathrm{Li}$ (or $\mathrm{O} / \mathrm{F} /-\mathrm{O} / \mathrm{F}$ ) distance of 4.08 $\AA$, resembling the length of the cubic unit cell, is again shorter than that in the structural model from the Rietveld refinement. The consecutive distances at 4.60 and $5.04 \AA$ match appear to match well again. An overview of the discussed distances is given in Table 1. The position of the reflections is determined by the space group symmetry and unit-cell dimensions. Thus, the deviations from the ideal peak positions in the PDF, given by the apparent cubic nature of the material, show that the local structure of $\mathrm{Li}_{2} \mathrm{VO}_{2} \mathrm{~F}$ is not the ideal cubic $F m \overline{3} m$ structure. The quality of the PDF fit significantly improves when the starting value of the fitting range is increased to exclude the short-range part. At a starting value of $3.5 \AA$ as for the $r$ range, the quality of the refined model is significantly improved (Figure S1). A good description of the DRS phase $\left(r_{\mathrm{w}}=10.393 \%\right)$ is obtained when the local range is excluded (Figure 1c).

The reason of the local bond length deviations might be related to some degree of order in the general randomized 
Table 1. Comparison of Distances in $\mathrm{Li}_{2} \mathrm{VO}_{2} \mathrm{~F}(\mathrm{Fm} \overline{3} m)$ Obtained from the Average Atomic Positions Calculated from the Rietveld Refinement and from Peak Positions in the Pair Distribution Function

$\begin{array}{lcc}\text { pair of atoms } & \text { Rietveld distance }(\AA) & \text { PDF distance }(\AA) \\ \mathrm{V} / \mathrm{Li}-\mathrm{O} / \mathrm{F} & 2.06 & 2.00 \\ \mathrm{~V} / \mathrm{Li}-\mathrm{V} / \mathrm{Li}^{a} & 2.91 & 2.95 \\ \mathrm{~V} / \mathrm{Li}-\mathrm{O} / \mathrm{F} & 3.56 & 3.57 \\ \mathrm{~V} / \mathrm{Li}-\mathrm{V} / \mathrm{Li}^{a} & 4.12 & 4.08 \\ \mathrm{~V} / \mathrm{Li}-\mathrm{O} / \mathrm{F} & 4.60 & 4.60 \\ \mathrm{~V} / \mathrm{Li}-\mathrm{V} / \mathrm{Li}^{a} & 5.04 & 5.04\end{array}$

${ }^{a}$ Have corresponding $\mathrm{O} / \mathrm{F}-\mathrm{O} / \mathrm{F}$ distances in the $F m \overline{3} m$ structure.

ionic environment, the disorder of the structure. For example, a simple estimation of bond lengths based on ionic radii ${ }^{19}$ shows that the $\mathrm{V}^{3+}-\mathrm{F}^{-}$bond $(1.97 \AA$ ) has a different length compared to the $\mathrm{V}^{3+}-\mathrm{O}^{2-}$ bond $(2.04 \AA)$. The same holds for $\mathrm{Li}^{+}-\mathrm{F}^{-}(2.09 \AA)$ and $\mathrm{Li}^{+}-\mathrm{O}^{2-}(2.16 \AA)$. Since $\mathrm{O}$ and $\mathrm{F}$ populate the same crystallographic position and their X-ray scattering factors are almost similar, we cannot differentiate between the atoms in the analysis of XRPD using the Rietveld method, but variations in the very local structure are visible in PDF. A fit over the whole range of 1.5-40 $\AA$ yields $r_{\mathrm{w}}=$ $19.065 \%$ (Figure S2). The resulting lattice parameter of the PDF fit over the full range is $a=4.114$ (3) Å, confirming the Rietveld refinement. The PDF fit further yields a sphere diameter ${ }^{20}$ for $\mathrm{Li}_{2} \mathrm{VO}_{2} \mathrm{~F}$ of $7.7 \pm 1.6 \mathrm{~nm}$.

2.2. Structural Evolution of $\mathrm{Li}_{2} \mathrm{VO}_{2} \mathrm{~F}$ during Battery Operation. Figure 2 shows the operando diffraction pattern of

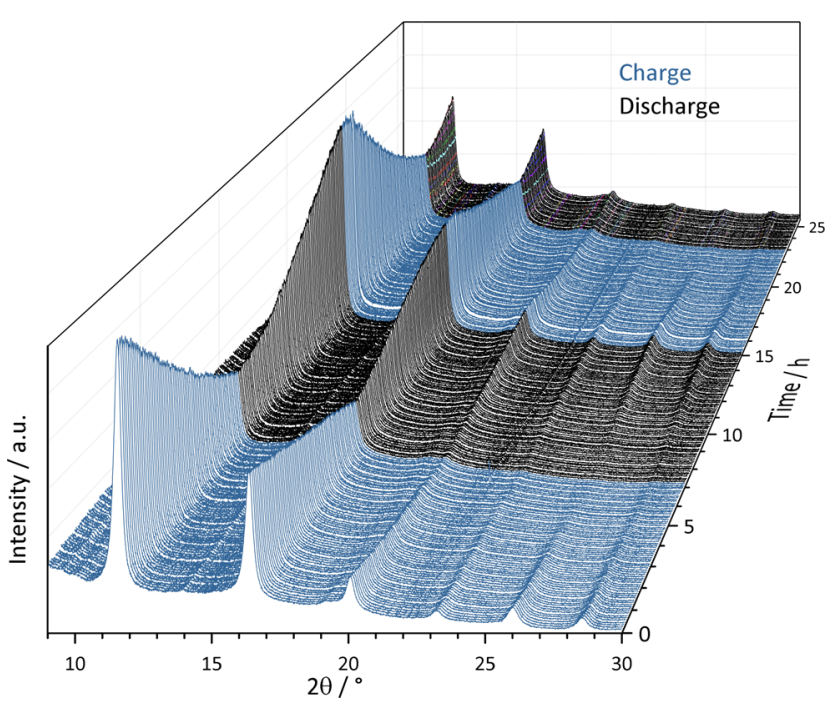

Figure 2. Operando XRPD patterns of the $\mathrm{Li}_{2} \mathrm{VO}_{2} \mathrm{~F}$ cathode while the capillary cell was charged (blue) and discharged (black) with a current of $\pm 30 \mu \mathrm{A}$ between 1.3 and $4.1 \mathrm{~V}$ vs. $\mathrm{Li} / \mathrm{Li}^{+}$. Note: the increasing intensity of the 111 reflection (at $10.1^{\circ} 2 \theta$ ) can be seen in Figure 3a.

$\mathrm{Li}_{2} \mathrm{VO}_{2} \mathrm{~F}$ for 1.5 cycles. Starting from open-circuit potential (OCV), the cell was cycled by charging it to $4.1 \mathrm{~V}$ vs. $\mathrm{Li} / \mathrm{Li}^{+}$ and subsequently discharging it to $1.3 \mathrm{~V}$ vs. $\mathrm{Li} / \mathrm{Li}^{+}$. The XRPD data show that the intensity of the diffraction peaks of the rock salt phase decreases drastically when $\mathrm{Li}$ is extracted but increases again during $\mathrm{Li}$ reinsertion. This behavior appears reversible. The magnitude of the decrease in the peak intensity is much larger than what can be expected if only $\mathrm{Li}$ is extracted, thereby reducing the average electron density at the Wyckoff $4 a$ sites. Looking at the intensity of the 200 reflection $\left(11.6^{\circ}\right.$ $2 \theta$ ), at the first charged state, it is only $39 \%$ of the initial peak intensity. When discharged, the peak intensity returns back to $96 \%$ of the initial peak intensity. The other even reflections behave similar. Interestingly, a drastic decrease in peak intensity has been observed in several ex situ XRPD studies on fluorinated and nonfluorinated DRS materials presented in the past, such as $\mathrm{Li}_{2} \mathrm{MoO}_{2} \mathrm{~F}^{5} \mathrm{Li}_{2.1} \mathrm{Mo}_{0.7} \mathrm{Ti}_{0.2} \mathrm{O}_{2} \mathrm{~F}_{2}{ }^{6}$ $\mathrm{Li}_{2} \mathrm{~V}_{0.2} \mathrm{Cr}_{0.8} \mathrm{O}_{2} \mathrm{~F},{ }^{7} \quad \mathrm{Li}_{2} \mathrm{MnO}_{2} \mathrm{~F},{ }^{8} \quad \mathrm{Li}_{2} \mathrm{Mn}_{0.5} \mathrm{Ti}_{0.5} \mathrm{O}_{2} \mathrm{~F},{ }^{21}$ $\mathrm{Li}_{1.25} \mathrm{Nb}_{0.25} \mathrm{~V}_{0.5} \mathrm{O}_{2}$, ${ }^{9}$ and $\mathrm{Li}_{1.2} \mathrm{Ni}_{0.33} \mathrm{Ti}_{0.33} \mathrm{Mo}_{0.13} \mathrm{O}_{2}$, ${ }^{10}$ but it has not been discussed in greater detail. In sulfide-based DRS materials like $\mathrm{Li}_{2} \mathrm{TiS}_{3}$, this phenomenon was discussed, suggesting a reversible amorphization of the structure. ${ }^{22,23}$ Since this feature seems to appear in many DRS compounds with very different elemental composition, it is likely that this amorphization during $\mathrm{Li}$ extraction and recrystallization during $\mathrm{Li}$ insertion are intrinsic properties of Li-rich DRS materials.

The high-quality synchrotron XRPD data reveal additional features during the electrochemical cycling of the material that have not been discussed anywhere yet. Figure 3a shows the top

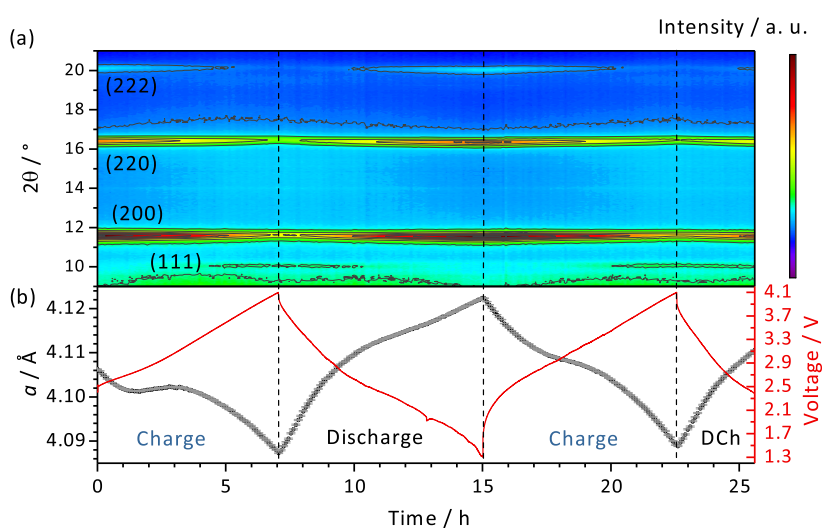

Figure 3. (a) Top view of the operando XRPD patterns of the $\mathrm{Li}_{2} \mathrm{VO}_{2} \mathrm{~F}$ cathode. While the intensities of the 200 (at $11.6^{\circ} 2 \theta$ ) and 222 (at $22.1^{\circ} 2 \theta$ ) reflections are decreasing during charging, the intensity of the 111 (at $10.1^{\circ} 2 \theta$ ) reflection is increasing. (b) Evolution of the $a$ unit-cell parameter of $\mathrm{Li}_{2} \mathrm{VO}_{2} \mathrm{~F}$ (left, with error bars) and voltage profile of the simultaneous galvanostatic cycling with a current of $\pm 30 \mu \mathrm{A}$ between 1.3 and $4.1 \mathrm{~V}$ vs. $\mathrm{Li} / \mathrm{Li}^{+}$.

view of the operando XRPD pattern. The 111 reflection (at $10.1^{\circ} 2 \theta$ ), which is barely visible in the pristine material (Figure 1a) deviates in its behavior from the 200,220 , and 2 22 reflections. Instead of decreasing, as discussed above, the intensity of 111 is slightly increasing upon $\mathrm{Li}$ extraction. Assuming that the charging process is solely associated with $\mathrm{Li}$ extraction, this would be unexpected since the overall electron density is decreasing due to $\mathrm{Li}$ extraction and the oxidation of $\mathrm{V}^{3+}$ to $\mathrm{V}^{5+}$. Hence, the increasing intensity of the $\begin{array}{lll}1 & 1 & 1\end{array}$ reflection in the charging process reveals that the Li extraction process is associated with additional structural reorganization and possibly with the development of a secondary phase, which is not visible in the diffracting patterns. The evolution of the $a$ unit-cell parameter based on the DRS $(F m \overline{3} m)$ structural model is presented in Figure $3 \mathrm{~b}$ with the corresponding cell voltage. The lattice parameter at the beginning of the measurement deviates slightly from the one obtained by the Rietveld refinement of the pristine powder (Figure S3). It is not possible to perfectly align the operando capillary cell in the 
beam, which will shift the peak positions very slightly. However, the relative changes remain valid and the differences are small. The small spike in the voltage profile during the first discharge at $1.8 \mathrm{~V}$ was induced due to gas bubble formation. During the first charge, when $\mathrm{Li}$ is extracted, the unit-cell parameter $a$ decreases by $0.5 \%$. Interestingly, between 2.5 and $2.9 \mathrm{~V}, a$ stops decreasing and increases again. This is unexpected since the voltage profile slope suggests a singlephase mechanism of Li extraction and reinsertion. ${ }^{1,3}$ Thus, the unit cell parameter should rather show further decrease upon $\mathrm{Li}$ extraction. A possible explanation could be an initial structural rearrangement of the DRS phase in the first charge. A similar behavior has so far been also observed in $\mathrm{Li}_{1.2} \mathrm{Ni}_{0.33} \mathrm{Ti}_{0.33} \mathrm{Mo}_{0.13} \mathrm{O}_{2}$ but was not further discussed. ${ }^{10}$ In $\mathrm{Li}_{1.25} \mathrm{Ni}_{0.45} \mathrm{Ti}_{0.3} \mathrm{Mo}_{0.1} \mathrm{O}_{1.85} \mathrm{~F}_{0.15}$, the lack of change in the lattice parameter during charging is referred to irreversible processes that do not lead to oxidation of any species in the lattice, such as the combined extraction of $\mathrm{Li}$ and $\mathrm{O} .{ }^{13}$ During the subsequent discharging, the unit cell parameter increases again by $0.9 \%$ when $\mathrm{Li}$ is reinserted. It further increases from the initial starting value at OCV. This could indicate that either additional $\mathrm{Li}$ is inserted into the structure, the process is associated with a structural transformation, or $\mathrm{Li}_{2} \mathrm{VO}_{2} \mathrm{~F}$ was $\mathrm{Li}$ deficient initially. The latter hypothesis has been discussed in the works of Chen et al. ${ }^{1}$ and Källquist et al. ${ }^{24}$ In the second charge, $a$ is shrinking again, reaching a similar value to that observed in the first charge. Overall, the evolution of the lattice parameter exhibits an inverse proportional sloping behavior to the voltage profile.

To better understand the changes in the local structure of $\mathrm{Li}_{2} \mathrm{VO}_{2} \mathrm{~F}$ during the cell operation, the PDF analysis was performed based on the X-ray total scattering data (Figure 4).

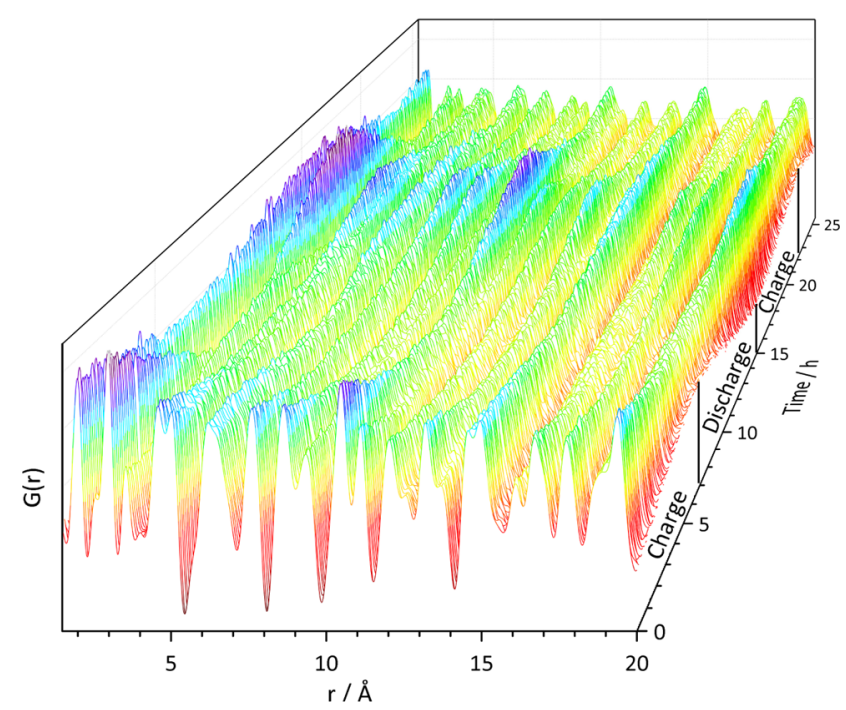

Figure 4. Operando PDF patterns of the $\mathrm{Li}_{2} \mathrm{VO}_{2} \mathrm{~F}$ cathode while the capillary cell was charged and discharged with a current of $\pm 30 \mu \mathrm{A}$ between 1.3 and $4.1 \mathrm{~V}$ vs. $\mathrm{Li} / \mathrm{Li}^{+}$.

During the charging process, the integrated intensity of the whole PDF decreases. In particular, the integrated intensity of the peaks of the characteristic distances of the $\mathrm{Li}_{2} \mathrm{VO}_{2} \mathrm{~F}$ DRS phase (e.g., at 2.0 and $2.9 \AA$, as discussed above) diminishes, indicating that the probability of having atoms at the distances in the structure reduces. From the diffraction data, it is evident that the structure partially turns amorphous during charging.
Correlating this observation with the operando PDF profiles, we find that the probability of characteristic distances of the DRS phase decreases significantly, when Li is extracted. This amorphization and loss of the DRS structure, however, appears to be reversible. During the subsequent discharging, the PDF pattern of the DRS structure reappears (Figures S4 and S5).

The weak intensity and the broader distribution of probabilities of the PDF in the charged state make it difficult to identify possible secondary phases. Hence, difference PDF patterns have been analyzed for the appearance and disappearance of distances, by subtracting operando PDF patterns in different state of charges (SOCs) from the initial operando PDF pattern at OCV. Figure $5 \mathrm{~b}$ shows the difference
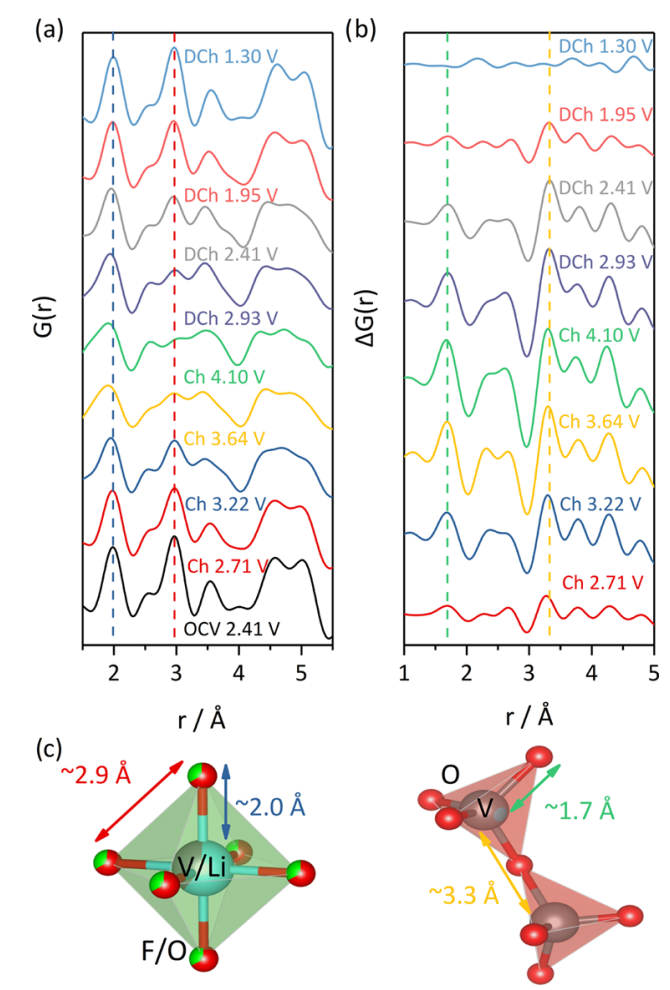

Figure 5. (a) PDF patterns of $\mathrm{Li}_{2} \mathrm{VO}_{2} \mathrm{~F}$ in different SOCs (based on cutoff voltages and $1 / 4,1 / 2$, and $3 / 4$ of the corresponding charge or discharge). The dotted lines indicate the $\mathrm{V} / \mathrm{Li}-\mathrm{O} / \mathrm{F}$ and $\mathrm{V} / \mathrm{Li}-\mathrm{V} / \mathrm{Li}$ (or $\mathrm{O} / \mathrm{F} /-\mathrm{O} / \mathrm{F}$ ) atomic distances. (b) Difference PDF of $\mathrm{Li}_{2} \mathrm{VO}_{2} \mathrm{~F}$ in different SOCs. The dotted lines indicate the evolving peaks, presumably originating from new appearing $\mathrm{V}-\mathrm{O}$ and $\mathrm{V}-\mathrm{V}$ atomic distance during cycling. (c) Schematic crystal structures of an octahedrally coordinated TM of a cubic structure $(F m \overline{3} m)$ and of a corner-sharing tetrahedrally coordinated $\mathrm{V}$ as it exists in $\mathrm{LiVO}_{3}(\mathrm{C} 2 /$ c) ${ }^{25}$ Characteristic distances are presented.

PDF patterns. With increasing SOC, new distances at 1.7, 3.3, 3.7, and $4.3 \AA$ are appearing. The DRS distances at 2.0 and 2.9 $\AA$ are achieving negative intensities, meaning that the probability of finding a pair of atoms at these distances is reduced. With decreasing SOC, the reverse behavior is observed, leading to an almost flat difference PDF profile for the discharged state at $1.3 \mathrm{~V}$. Thus, the DRS structure is reversibly formed again. $\mathrm{LiVO}_{3}$ with the monoclinic structure (space group $\mathrm{C} 2 / c)^{25}$ has similar characteristic distances as the ones derived from the operando PDF patterns during charging of the battery cell. $\mathrm{LiVO}_{3}$ consists of layers of corner-sharing $\left[\mathrm{VO}_{4}\right]$ tetrahedra chains (Figure 5c) alternating along the $a$ 
axis with $\mathrm{Li}-\mathrm{O}$ clusters in between. The $1.7 \AA$ distance may originate from the $\mathrm{V}-\mathrm{O}$ bond distances of the $\left[\mathrm{VO}_{4}\right]$ tetrahedron. The $3.3 \AA$ distance can be related to the distance between the neighboring $\mathrm{V}$ in the corner-sharing $\left[\mathrm{VO}_{4}\right]$ tetrahedra. The distances at 3.7, 4.3, and $4.7 \AA$ are comparable to the distances between $\mathrm{V}$ and other $\mathrm{O}$ atoms in the next corner-sharing $\left[\mathrm{VO}_{4}\right]$ tetrahedra. In fact, including the shortrange structural motif of $\mathrm{LiVO}_{3}$ as the secondary phase in the PDF analysis of the charged state, using a sphere diameter of $10 \AA$ to simulate a nanosized phase, improves the fit from 62 to $45 \% r_{\mathrm{w}}$ values (Figures S6 and S7). The $\beta$ angle of the $\mathrm{LiVO}_{3}$ unit cell with initial $110.5^{\circ}$ diminishes to $96^{\circ}$ in the PDF fit, more in the direction of a pseudo-orthorhombic unit cell motif. Also the $a$ unit cell parameter is decreasing by approximately $15 \%$ and the $b$ and $c$ unit cell parameters are increasing by 3 and $1 \%$, respectively. The strong distortion of the $\mathrm{LiVO}_{3}$ phase in the fit shows that the amorphous phase is not fully identical to the initial monoclinic $\mathrm{LiVO}_{3}$ and still does not describe the charged state ideally. Nevertheless, together with the difference PDF analysis, the results strongly suggest that some of the $\mathrm{V}$ atoms of the DRS phase move into tetrahedral coordination in an amorphous phase in the charged state. In the work of Källquist et al., the X-ray absorption data of $\mathrm{Li}_{2} \mathrm{VO}_{2} \mathrm{~F}$ show a strong increase in the intensity of the $\mathrm{V}$ K-edge preedge feature in the charged state. This intensive preedge feature is a strong indicator of the transition from octahedral to tetrahedral coordination geometry of $\mathrm{V}^{24}$ Also, Nakajima and Yabuuchi have reported a study of DRS $\mathrm{Li}_{1.25} \mathrm{Nb}_{0.25} \mathrm{~V}_{0.5} \mathrm{O}_{2}$, ${ }^{9}$ where X-ray absorption data indicate the existence of tetrahedrally coordinated V. However, it appears as if the authors assume that the tetrahedrally coordinated V remains in the DRS phase, whereas our study strongly indicates the existence cornersharing $\left[\mathrm{VO}_{4}\right]$ tetrahedra in a nondisordered rock salt amorphous phase in the charged state of the $\mathrm{Li}_{2} \mathrm{VO}_{2} \mathrm{~F}$ cathode material.

\section{CONCLUSIONS}

In conclusion, we report the first operando total diffraction study of $\mathrm{Li}_{2} \mathrm{VO}_{2} \mathrm{~F}$, a Li-rich DRS compound. Even though the material appears to exhibit the disordered rock salt structure in XRPD, the analysis of the PDF revealed deviations in the local range from the ideal cubic structure, the "pseudocubic" nature of the pristine material. In addition, we studied the structural evolution of $\mathrm{Li}_{2} \mathrm{VO}_{2} \mathrm{~F}$ during cell operation by operando XRPD and PDF analyses. The intensity loss of XRPD reflections during charging, which is observed in many similar Li-rich DRS compounds, is related to the amorphization of the structure. The DRS motif vanishes during $\mathrm{Li}$ extraction but recrystallizes when $\mathrm{Li}$ is reinserted. Moreover, we found strong indications for a local tetrahedral coordination of $\mathrm{V}$ in a nondisordered rock salt phase in the charged state, revealing a hidden structural reorganization during the $\mathrm{Li}$ extraction process. This work leads to new insights into Li-rich DRS materials and shows that amorphous material plays an important role in the $\mathrm{Li}$ extraction and insertion processes during battery operation of this DRS-like material.

\section{EXPERIMENTAL SECTION}

4.1. Synthesis and Preparation of Electrodes. All of the following steps, except ball milling, were conducted in an argon-filled glovebox with water and oxygen levels $<0.1 \mathrm{ppm}$. For the ball milling, the jars were filled inside the glovebox and sealed. The compounds were milled outside the glovebox. Disordered rock salt $\mathrm{Li}_{2} \mathrm{VO}_{2} \mathrm{~F}$ was synthesized following the high-energy ball milling procedure, as described by Baur et al., ${ }^{11,26}$ using a stoichiometric mixture of $\mathrm{V}_{2} \mathrm{O}_{3}$ (Alfa Aesar, 99.7\%), $\mathrm{Li}_{2} \mathrm{O}$ (Alfa Aesar, 99.7\%), and $\mathrm{LiF}$ (Alfa Aesar, 99.9\%). The obtained product was used without further purification. For the electrode preparation, $\mathrm{Li}_{2} \mathrm{VO}_{2} \mathrm{~F}$ was mixed with carbon black ( $\mathrm{CB}$, acetylene black, Alfa Aesar) in a ball mill for $3 \mathrm{~h}$ at $300 \mathrm{rpm}$ to obtain a composite of active material and carbon black. This composite was subsequently mixed with poly(vinylidene difluoride) (PVDF, Solvey), dissolved in N-methyl-2-pyrrolidone (NMP, Alfa Aesar, $99.5 \%$ ) in a mortar to obtain a slurry. The slurry was coated on flattened $\mathrm{Al}$ wires for the operando XRPD and on aluminum foil with a doctor blade $(250 \mu \mathrm{m}$ wet film thickness) for the electrochemical testing. The coated electrodes were dried in vacuum with stepwise increasing temperature up to $120^{\circ} \mathrm{C}$ for $12 \mathrm{~h}$.

4.2. Cell Assembly. For the operando XRPD measurements, specially designed capillary-based microbattery cells were used. Further information can be found in the Supporting Information (Figure S8) and in refs27, 28. ${ }^{27,28}$

4.3. Synchrotron X-ray Powder Diffraction. Synchrotron XRPD patterns were recorded at ALBA Synchrotron Light Source, Spain, at the BL04-Material Science and Powder Diffraction beamline. A wavelength of $\lambda=0.41324 \AA$ was used. The samples were measured in transmission geometry with a Mythen II detector. The ex situ powder samples were loaded into $0.7 \mathrm{~mm}$ borosilicate glass capillaries in an argon-filled glovebox and sealed. The diffraction data were collected to high values of momentum transfer $\left(Q_{\max }=26.0 \AA^{-1}\right)$.

The operando capillary-based microbattery cells were mounted horizontally in the beam and aligned from the position of the Bragg peaks of the $\mathrm{Al}$ current collector. The operando diffraction data were collected to $Q_{\max }=15.5 \AA^{-1}$ with a beam size of $2.00 \times 0.15 \mathrm{~mm}^{2}$. The acquisition time was $120 \mathrm{~s} / \mathrm{scan}$. Electrochemical cycling was conducted with a Biologic VMP potentiostat with a current of \pm 30 $\mu \mathrm{A}$ for charging and discharging (ca. C/10). The voltage range was $1.3-4.1 \mathrm{~V}$ vs. $\mathrm{Li} / \mathrm{Li}^{+}$. The tests were conducted at room temperature. The electrochemical performance of $\mathrm{Li}_{2} \mathrm{VO}_{2} \mathrm{~F}$ in the capillary-based microbattery cell behaves similarly to what is observed with conventional Swagelok-type cells (Figure S9).

4.4. X-ray Diffraction and Total Scattering Data Analysis. Rietveld refinement and sequential profile matching refinements were conducted using TOPAS version 5 software. ${ }^{29}$ The instrumental resolution function was determined using a $\mathrm{Ni}$ standard. For the Rietveld refinement, the $b$-factors were refined for the $4 a$ and $4 b$ Wyckoff sites. The occupancies for $\mathrm{O}=2 / 3$ and $\mathrm{F}=1 / 3$ were fixed based on the ideal stoichiometry. For the ex situ data, the occupancy of $\mathrm{Li}$ and $\mathrm{V}$ was restrained to add up to 1 and were refined. The atomic pair distribution function $G(r)$ was extracted from the total scattering data using PDFgetX3. ${ }^{30}$ For the total scattering data of the operando pattern, a constant background obtained from the capillarybased microbattery cell filled with electrolyte was subtracted. The $r_{\text {poly }}$ value was set to $0.95 \AA$. PDFgui was used to fit the structural models in real space. ${ }^{20}$ Instrumental broadening parameters $Q_{\text {damp }}$ and $Q_{\text {broad }}$ were determined by fitting a $\mathrm{Ni}$ standard. For fitting the operando PDF data, enlarged isotropic temperature factor in the $c$ direction of the graphite phase was included to model the contribution of carbon black in the electrode. The contribution of the PVDF binder was not accounted, due to the low amount in the electrode. Fityk version 1.3.1 ${ }^{31}$ was used to fit the peak positions in the PDF and difference PDFs using Gaussian functions. Crystal structures have been visualized using VESTA. ${ }^{32}$

\section{ASSOCIATED CONTENT}

SI Supporting Information

The Supporting Information is available free of charge at https://pubs.acs.org/doi/10.1021/acsami.0c02391.

XRPD Rietveld refinements, PDF fits, and results of $\mathrm{Li}_{2} \mathrm{VO}_{2} \mathrm{~F}$ as pristine powder; operando measurements at $\mathrm{OCV}$, charged and discharged; schematic illustration of the capillary-based microbattery cell used for the 
measurements; comparison of cycling profiles of the capillary-based microbattery cell used for the measurement; and a conventional Swagelok cell (PDF)

\section{AUTHOR INFORMATION}

\section{Corresponding Author}

Christian Baur - Helmholtz Institute Ulm, 89081 Ulm, Germany; Department of Energy Conversion and Storage, Technical University of Denmark, DK-2800 Kgs. Lyngby, Denmark; 이이.org/0000-0002-1512-2735;

Email: christian.baur@kit.edu

\section{Authors \\ Monica-Elisabeta Lǎcătuşu - Department of Energy Conversion and Storage, Technical University of Denmark, DK- 2800 Kgs. Lyngby, Denmark \\ Maximilian Fichtner - Helmholtz Institute Ulm, $89081 \mathrm{Ulm}$, Germany; Institute of Nanotechnology, Karlsruhe Institute of Technology (KIT), 76344 Eggenstein-Leopoldshafen, Germany \\ Rune E. Johnsen - Department of Energy Conversion and Storage, Technical University of Denmark, DK-2800 Kgs. Lyngby, Denmark}

Complete contact information is available at: https://pubs.acs.org/10.1021/acsami.0c02391

\section{Author Contributions}

C.B. and R.E.J. planned the project. C.B. synthesized the materials. The X-ray synchrotron data were acquired by R.E.J. with the help of C.B. and M.-E.L. The X-ray data were analyzed by C.B. and R.E.J. with the help of M.-E.L. The manuscript was written by C.B. with the help of R.E.J. and M.E.L. It was revised with the help of all authors.

\section{Notes}

The authors declare no competing financial interest.

\section{ACKNOWLEDGMENTS}

This project received funding from the European Union's Horizon 2020 research and innovation program (FET-OPEN project "LiRichFCC") under Grant Agreement No. 711792. DANSCATT is acknowledged for covering travel expenses in relation to the synchrotron experiment. These experiments were performed at BL04-Materials Science and Powder Diffraction beamline at ALBA Synchrotron with the collaboration of ALBA staff. The work is part of the platform CELEST (Center for Electrochemical Storage Ulm-Karlsruhe). Further, the authors thank Dr. Jin Hyun Chang (DTU) and Dr. Holger Euchner (HIU) for helpful discussion based on DFT modeling results.

\section{REFERENCES}

(1) Chen, R.; Ren, S.; Knapp, M.; Wang, D.; Witter, R.; Fichtner, M.; Hahn, H. Disordered Lithium-Rich Oxyfluoride as a Stable Host for Enhanced $\mathrm{Li}^{+}$Intercalation Storage. Adv. Energy Mater. 2015, 5, No. 1401814.

(2) Yabuuchi, N. Material Design Concept of Lithium-Excess Electrode Materials with Rocksalt-Related Structures for Rechargeable Non-Aqueous Batteries. Chem. Rec. 2019, 19, 690-707.

(3) Wang, X.; Huang, Y.; Ji, D.; Omenya, F.; Karki, K.; Sallis, S.; Piper, L. F. J.; Wiaderek, K. M.; Chapman, K. W.; Chernova, N. A.; Whittingham, M. S. Structure Evolution and Thermal Stability of High-Energy- Density Li-Ion Battery Cathode $\mathrm{Li}_{2} \mathrm{VO}_{2} \mathrm{~F}$. J. Electrochem. Soc. 2017, 164, A1552-A1558.
(4) Urban, A.; Lee, J.; Ceder, G. The Configurational Space of Rocksalt-Type Oxides for High-Capacity Lithium Battery Electrodes. Adv. Energy Mater. 2014, 4, No. 1400478.

(5) Takeda, N.; Hoshino, S.; Xie, L.; Chen, S.; Ikeuchi, I.; Natsui, R.; Nakura, K.; Yabuuchi, N. Reversible Li storage for nanosize cation/ anion-disordered rocksalt-type oxyfluorides: $\mathrm{LiMoO}_{2-x} \mathrm{LiF}(0 \leq x \leq$ 2) binary system. J. Power Sources 2017, 367, 122-129.

(6) Takeda, N.; Ikeuchi, I.; Natsui, R.; Nakura, K.; Yabuuchi, N. Improved Electrode Performance of Lithium-Excess Molybdenum Oxyfluoride: Titanium Substitution with Concentrated Electrolyte. ACS Appl. Energy Mater. 2019, 2, 1629-1633.

(7) Ren, S.; Chen, R.; Maawad, E.; Dolotko, O.; Guda, A. A.; Shapovalov, V.; Wang, D.; Hahn, H.; Fichtner, M. Improved Voltage and Cycling for $\mathrm{Li}^{+}$Intercalation in High-Capacity Disordered Oxyfluoride Cathodes. Adv. Sci. 2015, 2, No. 1500128.

(8) House, R. A.; Jin, L.; Maitra, U.; Tsuruta, K.; Somerville, J. W.; Förstermann, D. P.; Massel, F.; Duda, L.; Roberts, M. R.; Bruce, P. G. Lithium manganese oxyfluoride as a new cathode material exhibiting oxygen redox. Energy Environ. Sci. 2018, 11, 926-932.

(9) Nakajima, M.; Yabuuchi, N. Lithium-Excess Cation-Disordered Rocksalt-Type Oxide with Nanoscale Phase Segregation: $\mathrm{Li}_{125} \mathrm{Nb}_{0.25} \mathrm{~V}_{0.5} \mathrm{O}_{2}$. Chem. Mater. 2017, 29, 6927-6935.

(10) Lee, J.; Seo, D.-H.; Balasubramanian, M.; Twu, N.; Li, X.; Ceder, G. A new class of high capacity cation-disordered oxides for rechargeable lithium batteries: $\mathrm{Li}-\mathrm{Ni}-\mathrm{Ti}-\mathrm{Mo}$ oxides. Energy Environ. Sci. 2015, 8, 3255-3265.

(11) Baur, C.; Källquist, I.; Chable, J.; Chang, J. H.; Johnsen, R. E.; Ruiz-Zepeda, F.; Mba, J.-M. A.; Naylor, A. J.; Garcia-Lastra, J. M.; Vegge, T.; Klein, F.; Schür, A. R.; Norby, P.; Edström, K.; Hahlin, M.; Fichtner, M. Improved cycling stability in high-capacity Li-rich vanadium containing disordered rock salt oxyfluoride cathodes. $J$. Mater. Chem. A 2019, 7, 21244-21253.

(12) Cambaz, M. A.; Vinayan, B. P.; Pervez, S. A.; Johnsen, R. E.; Geßwein, H.; Guda, A. A.; Rusalev, Y. V.; Kinyanjui, M. K.; Kaiser, U.; Fichtner, M. Suppressing Dissolution of Vanadium from CationDisordered $\mathrm{Li}_{2-\mathrm{x}} \mathrm{VO}_{2} \mathrm{~F}$ via a Concentrated Electrolyte Approach. Chem. Mater. 2019, 31, 7941-7950.

(13) Lee, J.; Papp, J. K.; Clément, R. J.; Sallis, S.; Kwon, D.-H.; Shi, T.; Yang, W.; McCloskey, B. D.; Ceder, G. Mitigating oxygen loss to improve the cycling performance of high capacity cation-disordered cathode materials. Nat. Commun. 2017, 8, No. 981.

(14) Wiaderek, K. M.; Borkiewicz, O. J.; Castillo-Martínez, E.; Robert, R.; Pereira, N.; Amatucci, G. G.; Grey, C. P.; Chupas, P. J.; Chapman, K. W. Comprehensive insights into the structural and chemical changes in mixed-anion FeOF electrodes by using operando PDF and NMR spectroscopy. J. Am. Chem. Soc. 2013, 135, 40704078.

(15) Christensen, C. K.; Sørensen, D. R.; Hvam, J.; Ravnsbæk, D. B. Structural Evolution of Disordered $\mathrm{Li}_{\mathrm{x}} \mathrm{V}_{2} \mathrm{O}_{5}$ Bronzes in $\mathrm{V}_{2} \mathrm{O}_{5}$ Cathodes for Li-Ion Batteries. Chem. Mater. 2019, 31, 512-520.

(16) Zhao, E.; He, L.; Wang, B.; Li, X.; Zhang, J.; Wu, Y.; Chen, J.; Zhang, S.; Liang, T.; Chen, Y.; Yu, X.; Li, H.; Chen, L.; Huang, X.; Chen, H.; Wang, F. Structural and mechanistic revelations on high capacity cation-disordered Li-rich oxides for rechargeable Li-ion batteries. Energy Storage Mater. 2019, 16, 354-363.

(17) Chen, R.; Ren, S.; Yavuz, M.; Guda, A. A.; Shapovalov, V.; Witter, R.; Fichtner, M.; Hahn, $\mathrm{H}_{\text {. } \mathrm{Li}^{+}}$intercalation in isostructural $\mathrm{Li}_{2} \mathrm{VO}_{3}$ and $\mathrm{Li}_{2} \mathrm{VO}_{2} \mathrm{~F}$ with $\mathrm{O}^{2-}$ and mixed $\mathrm{O}^{2-} / \mathrm{F}^{-}$anions. Phys. Chem. Chem. Phys. 2015, 17, 17288-17295.

(18) Balzar, D.; Audebrand, N.; Daymond, M. R.; Fitch, A.; Hewat, A.; Langford, J. I.; Le Bail, A.; Louër, D.; Masson, O.; McCowan, C. N.; Popa, N. C.; Stephens, P. W.; Toby, B. H. Size-strain linebroadening analysis of the ceria round-robin sample. J. Appl. Crystallogr. 2004, 37, 911-924.

(19) Shannon, R. D. Revised effective ionic radii and systematic studies of interatomic distances in halides and chalcogenides. Acta Crystallogr., Sect. A 1976, 32, 751-767.

(20) Farrow, C. L.; Juhas, P.; Liu, J. W.; Bryndin, D.; Božin, E. S.; Bloch, J.; Proffen, T.; Billinge, S. J. L. PDFfit2 and PDFgui: computer 
programs for studying nanostructure in crystals. J. Phys. Condens. Matter 2007, 19, No. 335219.

(21) Lee, J.; Kitchaev, D. A.; Kwon, D.-H.; Lee, C.-W.; Papp, J. K.; Liu, Y.-S.; Lun, Z.; Clément, R. J.; Shi, T.; McCloskey, B. D.; Guo, J.; Balasubramanian, M.; Ceder, G. Reversible $\mathrm{Mn}^{2+} / \mathrm{Mn}^{4+}$ double redox in lithium-excess cathode materials. Nature 2018, 556, 185-190.

(22) Sakuda, A.; Takeuchi, T.; Okamura, K.; Kobayashi, H.; Sakaebe, H.; Tatsumi, K.; Ogumi, Z. Rock-salt-type lithium metal sulphides as novel positive-electrode materials. Sci. Rep. 2014, 4, No. 4483.

(23) Sakuda, A.; Ohara, K.; Kawaguchi, T.; Fukuda, K.; Nakanishi, K.; Arai, H.; Uchimoto, Y.; Ohta, T.; Matsubara, E.; Ogumi, Z.; Kuratani, K.; Kobayashi, H.; Shikano, M.; Takeuchi, T.; Sakaebe, H. A Reversible Rocksalt to Amorphous Phase Transition Involving Anion Redox. Sci. Rep. 2018, 8, No. 15086.

(24) Källquist, I.; Naylor, A. J.; Baur, C.; Chable, J.; Kullgren, J.; Fichtner, M.; Edström, K.; Brandell, D.; Hahlin, M. Degradation Mechanisms in $\mathrm{Li}_{2} \mathrm{VO}_{2} \mathrm{~F}$ Li-Rich Disordered Rock-Salt Cathodes. Chem. Mater. 2019, 31, 6084-6096.

(25) Shannon, R. D.; Calvo, C. Crystal Structure of $\mathrm{LiVO}_{3}$. Can. J. Chem. 1973, 51, 265-273.

(26) Baur, C.; Chable, J.; Klein, F.; Chakravadhanula, V. S. K.; Fichtner, M. Reversible Delithiation of Disordered Rock Salt $\mathrm{LiVO}_{2}$. ChemElectroChem 2018, 5, 1484-1490.

(27) Jung, Y. H.; Christiansen, A. S.; Johnsen, R. E.; Norby, P.; Kim, D. K. In Situ X-Ray Diffraction Studies on Structural Changes of a P2 Layered Material during Electrochemical Desodiation/Sodiation. Adv. Funct. Mater. 2015, 25, 3227-3237.

(28) Christiansen, A. S.; Johnsen, R. E.; Norby, P.; Frandsen, C.; Morup, S.; Jensen, S. H.; Hansen, K. K.; Holtappels, P. In Situ Studies of $\mathrm{Fe}^{4+}$ Stability in $\beta$ - $\mathrm{Li}_{3} \mathrm{Fe}_{2}\left(\mathrm{PO}_{4}\right)_{3}$ Cathodes for Li Ion Batteries. J. Electrochem. Soc. 2015, 162, A531-A537.

(29) Coelho, A. A. TOPAS and TOPAS-Academic: an optimization program integrating computer algebra and crystallographic objects written in C++. J. Appl. Crystallogr. 2018, 51, 210-218.

(30) Juhás, P.; Davis, T.; Farrow, C. L.; Billinge, S. J. PDFgetX3: A rapid and highly automatable program for processing powder diffraction data into total scattering pair distribution functions. $J$. Appl. Crystallogr. 2013, 46, 560-566.

(31) Wojdyr, M. Fityk: a general-purpose peak fitting program. J. Appl. Crystallogr. 2010, 43, 1126-1128.

(32) Momma, K.; Izumi, F. VESTA 3 for three-dimensional visualization of crystal, volumetric and morphology data. J. Appl. Crystallogr. 2011, 44, 1272-1276. 